\title{
Туруни (Carabidae) Ківерцівського національного природного парку «Цуманська пуща»: попередні дослідження
}

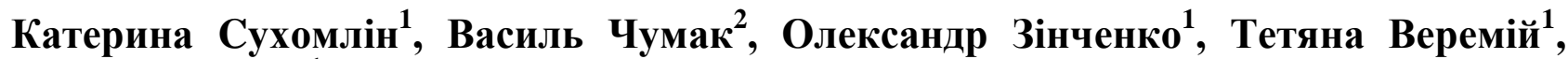 \\ Марія Зінченко
}

${ }^{\mathbf{1}}$ Волинський національний університет імені Лесі Українки, Луцьк, Україна

²Державний вищий навчальний заклад «Ужгородський національний університет», Ужгород, Україна Адреса для листування: Sukhomlin.Katerina@vnu.edu.ua, Zinchenko.Oleksandr@vnu.edu.ua

Резюме. Робота відображає підсумки першого вивчення турунів у межах Ківерцівського національного природного парку «Цуманська пуща» - унікальної природної пам'ятки на північному заході України. Національний природний парк розташований у межах Ківерцівського адміністративного району Волинської області і займає площу 33475,34 га. Створений на базі найбільш цінних дубових та сосново-дубових лісових масивів. Дослідження проводили у 2017-2019 рр. методами маршрутних зборів та косіння ентомологічним сачком. Обстежено заплавні луки р. Конопельки поблизу с. Сокиричі, с. Муравище, с. Пальче, ліс в урочищі Папики поблизу с. Дерно, ліс поблизу с. Дачне, луки та ліс поблизу смт Цумань, ліс поблизу м. Ківерці, заплави річок Путилівки (с. Ставок, смт Цумань), Кормин (поблизу с. Берестяне), Рудки (неподалік с. Журавичі), Грушвиці (неподалік с. Омельне), меліоративні канали та луки навколо них (с. Дерно, смт Цумань).

У Ківерцівському національному природному парку «Цуманська пуща» зареєстровано 39 видів турунів, що належать до 20 родів. Найбільше видове різноманіття має рід Pterostichus, до якого належить 8 видів. Тільки на згарищі зареєстровано 8 видів: Agonum sexpunctatum, Amara communis, Amara curta, Amara tibialis, Bembidion lampros, Dyschirius globosus, Poecilus versicolor, Pterostichus minor, лише в сосновому лісі виявлено Amara familiaris, лише в дубовому лісі трапляються 15 видів: Agonum gracilipes, Amara aenea, Calosoma inquisitor, Carabus coriaceus, Carabus hortensis, Harpalus latus, Leistus rufomarginatus, Leistus terminates, Limodromus assimilis, Nebria brevicollis, Notiophilus biguttatus, Pterostichus melanarius, Pterostichus strenuous, Stomis pumicatus, Synuchus vivalis. Видове багатство зростає за градієнтом: сосновий ліс - дубовий ліс - згарище. У сосновому лісі індекс Маргалефа становить 1,93 , у дубовому - 3,55, на колишньому згарищі - 4,42. Найбільшу спільність видів турунів мають біотопи дубового лісу і згарища $(0,48)$, середній показник спільності властивий для лісових біотопів $(0,44)$, найменша подібність видового складу турунів властива біотопам соснового лісу та згарища $(0,28)$.

Ключові слова: туруни, видовий склад, поширення, біотопічна приуроченість.

\section{Carabidae of Kivertsy National Nature Park "Tsumanska Pushcha": preliminary research}

\section{Kateryna Sukhomlin, Vasyl Chumak, Oleksandr Zinchenko, Tetyana Veremiy, Maria Zinchenko}

Lesya Ukrainka Volyn National University, Lutsk, Ukraine

Correspondence: Sukhomlin.Katerina@vnu.edu.ua, Zinchenko.Oleksandr@vnu.edu.ua

\begin{abstract}
This paper reflects the results of the first study of Carabidae in the Kivertsy National Nature Park «Tsumanska Pushcha» - the unique natural monument in northwestern Ukraine. This National Park is located in the Kivertsy administrative district of Volyn region and covers an area of 33475,34 ha. It was created on the basis of the most valuable oak and pine-oak forests. The research was conducted in 2017-2019 by the methods of route collection and mowing with an entomological net. The floodplain meadows of the Konopelka River near the village of Sokyrychi, vil. Muravishche, vil. Palche, forest in the Papyky hole near the vil. Derno, forest near
\end{abstract}


the vil. Dachne, meadows and forest near vil. Tsuman, forest near Kivertsi, floodplains of Putylivka rivers (vil. Stavok, vil. Tsuman), Kormyn (near vil. Berestyane), Rudky (near vil. Zhuravychi), Hrushvytsia (near vil. Omelne), reclamation canals and meadows around them (vil. Derno, vil. Tsuman) were inspected.

In the Kivertsy National Nature Park «Tsumanska Pushcha» was registered 39 species of Carabidae belonging to 20 genera. The genus Pterostichus has the greatest variety of species, which includes 8 species. Only 8 species were registered in the site of fire: Agonum sexpunctatum, Amara communis, Amara curta, Amara tibialis, Bembidion lampros, Dyschirius globosus, Poecilus versicolor, Pterostichus minor, Amara gramisis was found only in the pine forest, only in the oak forest there were 15 species: Agonum gracilipes, Amara aenea, Calosoma inquisitor, Carabus coriaceus, Carabus hortensis, Harpalus latus, Leistus rufomarginatus, Leistus terminates, Limodromus assimilis, Nebria brevicollis, Notiophilus biguttatus, Pterostichus melanarius, Pterostichus virunicus, Stteuchicus pumnechusus, Strenuicus pumnechus. Species diversity grows along the gradient: pine forest - oak forest - the site of fire. In the pine forest the Margalef index is 1.93, in the oak - 3.55, in the site of fire -4.42 . Oak forest and site of fire habitats have the greatest commonality of Carabidae species (0.48), the average commonality index is typical for forest biotopes $(0.44)$, the smallest similarity of Carabidae species composition is characteristic of pine forest and site of fire habitats (0.28).

Key words: Carabidae, species composition, distribution, biotope belonging.

\section{ВСТУП}

У роботі підведено попередні підсумки вивчення турунів у межах Ківерцівського національного природного парку «Цуманська пуща» - унікальної природної пам'ятки на північному заході України. Ківерцівський НПП «Цуманська пуща» розташований у межах Ківерцівського адміністративного району Волинської області і займає площу 33475,34 га. НПП створено на базі найбільш цінних дубових та сосново-дубових лісових масивів: державних лісогосподарських підприємств Цуманського та Ківерцівського лісових господарств, Волинського військового лісгоспу «Львівського військового лісокомбінату».

Вивчення природних комплексів Цуманської пущі розпочалося з 2002 року під керівництвом Наукового центру заповідної справи Мінекоресурсів України. За його дорученням співробітники Інституту зоології НАН України О. О. Байдашников, З. Л. Берест та О. Ю. Мороза розпочали вивчення безхребетних тварин Цуманських лісів [1]. Поблизу с. Берестяне та смт Цумань дослідники зареєстрували 1 вид червів (п'явку медичну), 38 видів наземних молюсків, 24 види рідкісних комах, серед яких 4 види жуків: жук-олень Lucanus cervus Linnaeus, 1758, плавунець широкий Dytiscus latissimus (Linnaeus, 1758), вусач великий дубовий західний Cerambyx cerdo Linnaeus, 1758, турун зморшкуватий Carabus intricatus, Linnaeus, 1761. У літописі природи парку [2] зазначено лише 25 видів комах, серед яких лише один турун зморшкуватий Carabus intricatus. Подальше дослідження турунів Волинського Полісся пов'язане з іменами О. М. Кравченка [3], який на території Шацького НПП відзначив 120 видів турунів 344 родів, В. Б. Різуна та В. О. Чумака [4], які зареєстрували 78 видів 331 роду, серед яких 8 видів нові для карабідофауни Волинського Полісся. Автори відзначають, що загалом фауна жуків-турунів Волинського (Західного) Полісся нараховує 151 вид. Крім того, автори звертають увагу на нерівномірність дослідження видового різноманіття турунів на території Волинського Полісся і недостатність досліджень в межах Ківерцівсько-Цуманського фізико-географічного району.

\section{МАТЕРІАЛ I МЕТОДИ ДОСЛІДЖЕНЬ}

Дослідження жуків-турунів проводилося 3 01 травня до 01 жовтня 2019 року в Ківерцівському національному природному парку НПП «Цуманська пуща» у трьох біотопах:

1) згарище - 1 пастка, пробна площа П-1 50 86' 93" пн.ш., 25 91' 96" сх.д. (рис. 1);

2) сосновий ліс - 1 пастка, пробна площа П1 - 50 87' 09" пн.ш., 25 91' 60" сх.д.;

3) дубовий ліс - 8 пасток, пробна площа П-2 - 50 92' 89" пн.ш., 25 87' 82" сх.д. (рис. 2).

Загалом було закладено 10 пасток (рис. 2), вміст перевіряли один раз на місяць. За досліджуваний період зібрано 2777 особин жуків-турунів.

Для проведення дослідження використовували такі загальновизнані ентомологічні методи [5]: відловлювання за допомогою пасток Барбера; розбір трухлої деревини, лісової підстилки, обстеження поверхні грунту.

На першому етапі дослідження збір матеріалу проводили шляхом відлову турунів на постійних пробних площах, установлених у лісовому масиві.

В нашому випадку пасткою Барбера була стандартна поліпропіленова склянка, об'ємом 0,5 л, із вхідним отвором діаметром 72 мм (рис. 2.2.), прозора ( вона має добрий 

імені Лесі Українки. Серія: Біологічні науки, 2020, 2 (390)

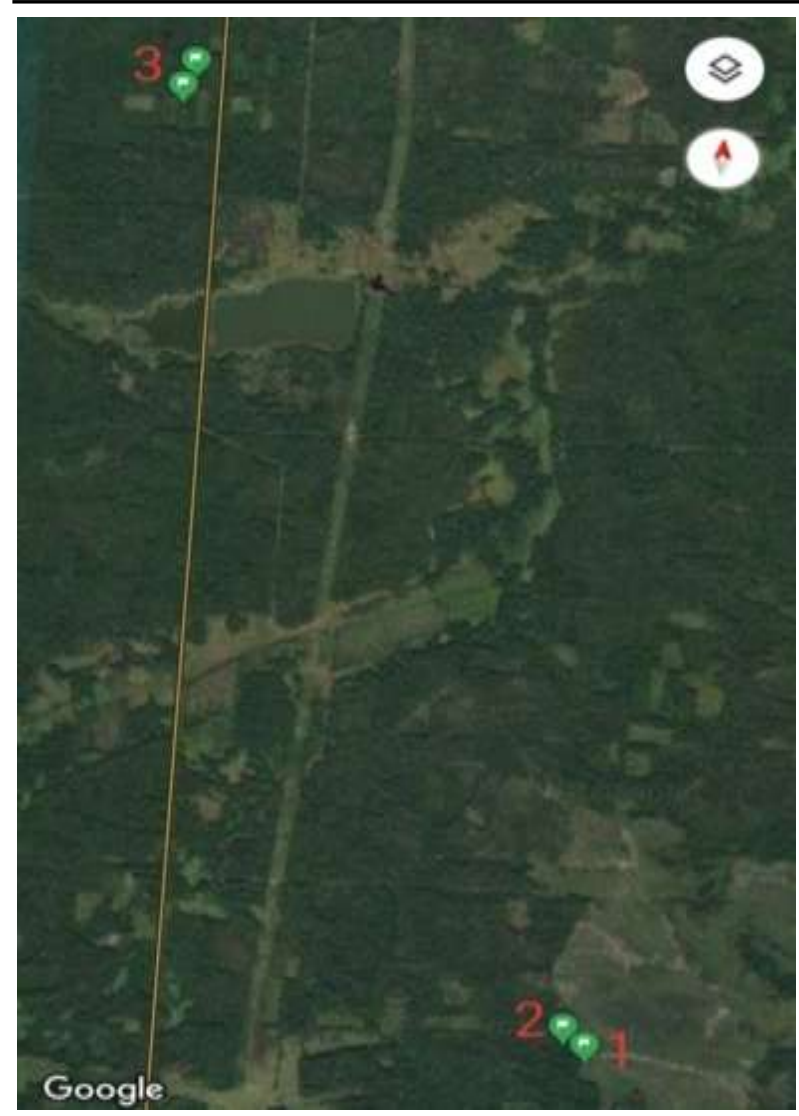

Рис. 1. Розташування пасток Барбера в НПП «Цуманська пуща»

маскувальний ефект та не привертає уваги сторонніх осіб). Механізм дії пасток полягає у тому, що комахи потрапляють до них, коли їхній маршрут переміщення перетинає місце розташування пристрою. Метод пасток дозволяє враховувати не реальну щільність популяції кожного виду на площі, а лише динамічну іï щільність [5].

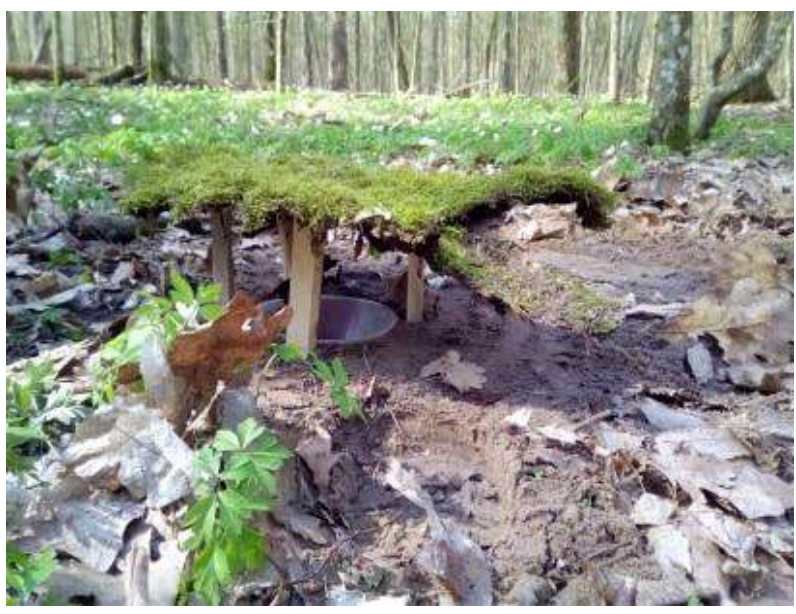

Рис. 2. Пастка Барбера у дубовомі лісі

Для фіксування комах, які потрапляють у пастку, використовували $4 \%$-й розчин формаліну. Для уникнення зайвої уваги та для захисту від погодних умов пастку прикрили зверху місцевим «матеріалом» (шматками сухої кори дерев, дошками, тріскою, шматком шиферу), тільки так, що між ними і поверхнею землі залишилась щілина для вільного проникнення комах. Зібраних комах зберігали в скляній банці, що заповнена 70\% спиртом.

На другому етапі дослідження, для повноти характеристики ентомофауни герпетобіонтів, проведено ручні збори жуків під корою повалених дерев, під наносами сміття на берегах водойм НПП «Цуманська пуща», на грунті. Знайдених комах збирали пінцетом у заздалегідь приготовані пробірки.

Таксономічний розподіл видів здійснено відповідно до Національної мережі інформації 3 біорізноманіття [6]. Визначення проведено за відповідними визначниками [7-9] та інтернетресурсами [10].

Для встановлення показників чисельності та поширення підраховували відповідні індекси.

Для підрахунку видового різноманіття турунів у різних біотопах використовували індекс видового багатства Маргалефа. Це співвідношення числа видів до числа особин (біомаси або щільності виду). Різноманітні співвідношення $\boldsymbol{S}$ і $\boldsymbol{N}$ лежать в основі простих показників видового різноманіття. Індекс видового багатства Маргалефа:

$$
D_{M g}=S-1 / \ln N \text {, }
$$

де $\boldsymbol{S}$ - число виявлених видів, $\boldsymbol{N}$ - загальне число особин усіх $\boldsymbol{S}$ видів.

Для характеристики біорізноманіття карабідофаун окремих біотопів вико ристовували індекс Чекановського-Серенсена, що дозволяє проаналізувати ступінь подібності двох різних фаун.

$$
D_{C S}=2 a /(a+b)+(a+c),
$$

де $\boldsymbol{a}$ - кількість спільних видів для обох територій, $\boldsymbol{b}$ - кількість видів, що зазначені тільки для першої території, $\boldsymbol{c}$ - кількість видів, що відзначені тільки для другої території.

\section{РЕЗУЛЬТАТИ}

У пунктах збору було зареєстровано 39 видів турунів Carabidae, що належать до 19 родів, у колекційних фондах кафедри зоології ВНУ зберігаються ще 3 види. Нижче наведено фауністичний список з указаними для кожного виду місцями збору та кількістю матеріалу. 
Туруни (Саrabidae) Ківериівського начіонального природного парку «Цуманська пуща»: попередні дослідження

\begin{tabular}{l}
\hline Ряд ТВЕРДОКРИЛІ або ЖУКИ - \\
СОLЕОРТЕRА Linnaeus, 1758 \\
Підряд ХИЖІ ЖУКИ - АDЕРНАGA \\
Schellenberg, 1806 \\
Надродина ТУРУНОЇДНІ - CARAВОIDEA \\
Latreille, 1802 \\
Родина Carabidae Latreille, 1802 - Туруни \\
або Жужелиці
\end{tabular}

Підродина Carabinae Latreille, 1802

Рід: Calosoma Weber, 1801 - Красотіл

1. C. inquisitor Linnaeus, 1758 - Красотіл бронзовий: дубовий ліс, 08.06.2019 - 2 екз.

2. C. sycophanta (Linnaeus, 1758) - Красотіл пахучий: пам'ятка природи «Горинські крутосхили», дубовий ліс, 18.06.1995 - 1 екз.

Рід Carabus Linnaeus, 1758 - Турун

3. C. arcensis Herbst, 1784 - Турун польовий: згарище, 17.05.2019 - 3 екз., 18.06.2019 - 4 екз.; дубовий ліс, 17.05.2019 - 3 екз., 08.06.2019 20 екз., 12.07.2019 - 23 екз., 09.08.2019 - 4 екз., 04.09.2019- 2 екз.

4. C. coriaceus Linnaeus, 1758 - Турун шагреневий: с. Дерно, ур. Папики, сосноводубовий ліс, 05.07.2018 - 2 екз.; дубовий ліс, 08.06.2019 - 2 екз., 12.07.2019 - 8 екз., 09.08.2019 - 2 екз., 04.09.2019 - 23 екз.

5. C. hortensis Linne, 1758 - Турун садовий: с. Дерно, ур. Папики, сосново-дубовий ліс, 05.07.2018 - 1 екз.; дубовий ліс, 17.05.2019 8 екз., 08.06.2019 - 17 екз., 12.07.2019 - 25 екз., 09.08.2019 - 20 екз., 04.09.2019 - 29 екз.

6. C. glabratus Paykull, 1790 - Турун чорний лісовий, Турун гладенький: с. Дерно, ур. Папики, сосново-дубовий ліс, 05.07.2018 1 екз.; сосновий ліс, 17.05.2019 - 1 екз.; дубовий ліс, 17.05.2019 - 7 екз., 08.06.2019 82 екз., 12.07.2019 - 26 екз., 09.08.2019 73 екз., 04.09.2019 - 27 екз.

7. Carabus violaceus Linnaeus, 1758 - Турун фіолетовий: згарище, 08.06.2019 - 1 екз.; дубовий ліс, 12.07.2019 - 18 екз., 09.08.2019 44 екз., 04.09.2019 - 41 екз.

8. C. caraboides (Linnaeus, 1758) - Турунслимакоїд: с. Дерно, ур. Папики, сосноводубовий ліс, 05.07.2018 - 1 екз.; сосновий ліс, 17.05.2019 - 1 екз.; дубовий ліс, 08.06.2019 11 екз., 12.07.2019 - 14 екз., 09.08.2019 22 екз., 04.09.2019 - 52 екз.

Підродина Chlaeniinae

Рід Chlaenius Bonelli, 1810 - Слимакоїд

9. C. tibialis (Dejean, 1826): с. Дерно, ур. Папики, сосново-дубовий ліс, 05.07.2018 1 екз.; згарище, 17.05.2019 - 1 екз., 12.07.2019 1 екз., 04.09.2019- 1 екз.

Підродина Harpalinae Bonelli, 1810 Харпаліни

Рід Harpalus Latreille, 1802 -Бігун

10. H. affinis (Schrank, 1781) - Бігун золотистий: c. Дерно, ур. Папики, луки, 05.07.2018 - 1 екз.

11. H. latus (Linnaeus, 1758) - Бігун золотистий: дубовий ліс, 17.05.2019 - 1 екз., 08.06.2019 - 12 екз., 12.07.2019 - 3 екз., 04.09.2019 - 1 екз.

12. H. rufipes (De Geer, 1774): c. Дерно, поле, 09.07.2017 - 1 екз.; околиці м. Ківерці, сосноводубовий ліс, 25.05.2018 - 1 екз.; смт Цумань, луки, 20.06.2018 - 1 екз.; с. Дерно, ур. Папики, сосново-дубовий ліс, 05.07.2018 - 1 екз.; згарище, 12.07.2019 - 1 екз.; дубовий ліс, 04.09.2019 - 1 екз.

Рід: Synuchus Gyllenhal, 1810

13. S. vivalis (Illiger, 1798) дубовий ліс, 12.07.2019 - 1 екз. 1834

Підродина Nebriinae Laporte de Castelnau,

\section{Рід: Leistus Frolich, 1799}

14. L rufomarginatus Duftschmid, 1812: дубовий ліс, 17.05.2019 - 1 екз., 08.06.2019 1 екз., 12.07.2019 - 2 екз.

15. L terminatus (Panzer, 1793) - Лейстус рудуватий: дубовий ліс, 04.09.2019 - 1 екз.

Рід: Nebria Latreille, 1802

16. N. brevicollis (Fabricius, 1792): дубовий ліс, 17.05.2019 - 2 екз., 08.06.2019 - 2 екз., 12.07.2019 - 1 екз., 04.09.2019 - 4 екз.

Рід: Notiophilus Dumeril, 1806

17. N. biguttatus (Fabricius, 1779): дубовий ліс, 17.05.2019 - 1 екз., 08.06.2019 - 3 екз., 12.07.2019 - 4 екз., 04.09.2019 - 1 екз.

18. N. palustris (Duftschmid, 1812): згарище, 17.05.2019 - 1 екз., 12.07.2019 1 екз.; дубовий ліс, 17.05 .2019 - 7 екз., 08.06.2019 - 33 екз., 12.07.2019 - 3 екз., 04.09.2019- 25 екз.

Підродина Platyninae Bonelli, 1810

Рід: Agonum Bonelli, 1810 - Бистряк

19. A. gracilipes (Duftschmid, 1812): дубовий ліс, 17.05.2019- 1 екз.

20. A. sexpunctatum (Linnaeus, 1758) Бистряк шестикрапковий: згарище, 12.07.2019 2 екз.

Рід: Calathus Bonelli, 1810

21. C. micropterus (Duftschmid, 1812): згарище, 12.07.2019 - 1 екз., 04.09.2019 - 1 екз.; дубовий ліс, 17.05.2019 - 1 екз., 08.06.2019 7 екз., 12.07.2019 - 7 екз., 09.08.2019 - 32 екз., 04.09.2019 - 51 екз.

Рід: Limodromus Motschulsky, 1850

22. L. assimilis (Paykull, 1790 ): дубовий ліс, 08.06.2019 - 6 екз.

Рід: Oxypselaphus Chaudoir, 1843 
Науковий вісник Східноєвропейського національного університету імені Лесі Українки. Серія: Біологічні науки, 2020, 2 (390)

23. O. obscurus (Herbst, 1784): Згарище, 17.05.2019 - 1 екз., 12.07.2019 - 1 екз., 09.08.2019 - 1 екз.; дубовий ліс, 17.05.20199 екз., 08.06.2019 - 53 екз., 12.07.2019 - 56 екз., 09.08.2019 - 17 екз., 04.09.2019 - 4 екз.

Підродина Pterostichinae Bonelli, 1810

Рід: Amara Bonelli, 1810

24. A. aenea (DeGeer, 1774) - Щурик блискучий: дубовий ліс, 08.06.2019 - 1 екз.

25. A. communis (Panzer, 1797) - Щурик лісовий: згарище, 17.05.2019 - 1 екз., 12.07.2019 -1 екз.

26. A. curta Dejean, 1828: Згарище, 17.05.2019 - 4 ек3., 08.06.2019 - 1 екз., 09.08.2019 - 1 екз.

27. A. familiaris (Duftschmid, 1812) - Щурик жовтоносий: сосновий ліс, 17.05.2019-1 екз.

28. A. tibialis (Paykull, 1798): Згарище, 17.05.2019 - 1 екз., 12.07.2019 - 1 екз., 09.08.2019 - 1 екз., 09.08.2019 - 1 екз.

29. A. littorea C.G.Thomson, 1857: Згарище, 17.05.2019 - 1 екз., 12.07.2019 - 1 екз.; сосновий ліс, 17.05.2019 - 9 екз.; дубовий ліс, 08.06.2019 - 2 екз., 12.07.2019 - 2 екз.

Рід: Poecilus Bonelli, 1810

30. P. versicolor (Sturm, 1824): Згарище, 17.05.2019 - 6 екз. 08.06.2019 - 15 екз., 12.07.2019 - 2 екз.

Рід Pterostichus Bonelli, 1810 - Птеростих

31. P. angustatus Letzner, 1852: Згарище, 08.06.2019 - 1 екз. 12.07.2019 - 1 екз.; сосновий ліс, 17.05.2019 - 1 екз.

32. P. oblongopunctatus (Fabricius, 1787): згарище, 17.05.2019 - 1 екз; сосновий ліс, 17.05.2019 - 1 екз; дубовий ліс, 17.05.2019 128 екз., 08.06.2019 - 263 екз., 12.07.2019 121 екз., 09.08.2019 - 61 екз., 04.09.2019 63 екз.

33. P. melanarius (Illiger, 1798): дубовий ліс, 08.06.2019 - 1 екз., 12.07.2019 - 4 екз.

34. P. diligens (Sturm, 1824): Згарище, 17.05.2019 - 4 екз., 12.07.2019 - 1 екз., 09. 08.2019 - 1 екз.; дубовий ліс, 08.06.2019 - 2 екз.

35. P. strenuиs (Panzer, 1796): дубовий ліс, 17.05.2019 - 2 екз., 08.06.2019 - 1 екз., 12.07.2019 - 1 екз.

36. P. niger (Schaller, 1783) - Птеростих чорний: с. Дерно, ур. Папики, сосново-дубовий ліс, 05.07.2018 - 1 екз.; згарище, 04.09.2019 1 екз.; дубовий ліс, 17.05.2019 - 1 екз., 08.06.2019 - 19 екз., 12.07.2019 - 157 екз., 09.08.2019 - 320 екз., 04.09.2019 - 419 екз.

37. P. minor (Gyllenhal, 1827): Згарище, 12.07.2019 - 2 екз.

38. P. nigrita (Paykull, 1790): Згарище, 12.07.2019 - 1 екз.; сосновий ліс, 17.05.2019-
3 екз.; дубовий ліс, 17.05.2019 - 6 екз., 08.06.2019 - 19 екз., 12.07.2019 - 31 екз., 09.08.2019- 45 екз.

Рід: Stomis Clairville, 1806

39. Stomis pumicatus (Panzer, 1796): дубовий ліс, 09.08.2019 - 2 екз.

Підродина Scaritinae Bonelli, 1810

Рід: Dyschirius Bonelli, 1810

40. D. globosus (Herbst, 1784): З згарище, 12.07.2019 - 11 екз., 09.08.2019 - 2 екз., 09.08.2019 - 1 екз.

Підродина Trechinae Bonelli, 1810

Рід: Bembidion Latreille, 1802 - Бігунчик

41. B. lampros (Herbst, 1784) - Бігунчик блискучий: згарище, 12.07.2019 - 4 екз.

Рід: Trechus Clairville, 1806 - Трехус

42. T. quadristriatus (Schrank, 1781) - Tpexyc чотириямковий: згарище, 12.07.2019 - 1 екз.; дубовий ліс, 08.06.2019 - 1 екз., 12.07.2019 1 екз., 09.08.2019 - 3 екз., 04.09.2019- 8 екз.

\section{ОБГОВОРЕННЯ РЕЗУЛЬТАТІВ}

За результатами зборів на території Ківерцівського національного природного парку «Цуманська пуща» та аналізу колекційних фондів кафедри зоології ВНУ родина Туруни (Carabidae) представлена 42 видами 319 родів. Порівняння 3 попередніми дослідженнями [3] довело поширення в межах Ківерцівського НПП «Цуманська пуща» 5 видів, які раніше були відзначені у Шацькому НПП: Agonum expunctatum, Amara familiaris, Calosoma inquisitor, Carabus glabratus, Poecilus rufipes та 6 видів, які не були зареєстровані у Волинському Поліссі [4]: Amara tibialis, Leistus rufomarginatus, Limodromus assimilis, Nebria brevicollis, Trechus quadristriatus.

Експедиція 3 вивчення природних комплексів Цуманської пущі 2002 року в складі співробітників Інституту зоології НАН України

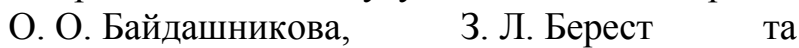
О. Ю. Мороз зареєструвала 1 вид турунів серед 4 видів рідкісних жуків: жук-олень Lucanus cervus, плавунець широкий Dytiscus latissimus, вусач великий дубовий західний Cerambyx cerdo, турун зморшкуватий Carabus intricatus [1]. Необхідно зауважити, що в колекційних фондах кафедри зоології ВНУ імені Лесі Українки зберігаються твердокрилі з Червоної книги України, зібрані в різні роки на території пам'ятки природи «Горинські крутосхили», зокрема, красотіл пахучий Calosoma sycophanta (Linnaeus, 1758) - 1 ек3, 18.06.1995.

Важливим показником оцінки різноманіття для обмеженого в просторі і часі угруповання, 
Туруни (Сатаbidae) Ківериівського національного природного парку «Цуманська пуща»: попередні дослідження

для якого чітко відомо число видів і особин, що його складають, є видове багатство. Однак у більшості випадків складно мати повний список видів угруповання. У цьому випадку використовували індекс Маргалефа співвідношення числа видів до чітко обумовленого числа особин. Різноманітні співвідношення $\boldsymbol{S}$ і $\boldsymbol{N}$ лежать в основі простих показників видового різноманіття. Перевага цього індексу - простота розрахунків. Індекс Маргалефа відображає щільність видів, або видове багатство, на певній території, а отже, чим більший показник індексу, тим більше видове багатство має певна територія. I3 збільшенням його значень зростає біорізноманіття. Індекс Маргалефа має максимальне значення, якщо всі особини належать до різних видів $(\boldsymbol{S}=\boldsymbol{n})$ і дорівнює нулю, коли всі особини належать до одного виду $(\boldsymbol{S}=\boldsymbol{1})$.

Індекс видового багатства Маргалефа для турунів згарища становить:

$D_{M g}=(S-1) / \ln N=(21-1) / \ln 92=20 / 4,52$ $=4,42$.

Індекс видового багатства Маргалефа для турунів соснового лісу становить: 1,93 .

$D_{M g}=(S-1) / \ln N=(8-1) / \ln 37=7 / 3,61=$

Індекс видового багатства Маргалефа для турунів дубового лісу становить:

$D_{M g}=(S-1) / \ln N=(29-1) / \ln 2648=28 /$ $7,88=3,55$.

Видове багатство зростає за градієнтом: сосновий ліс - дубовий ліс - згарище.

\section{Таблиия 1 \\ Спільність видів турунів різних біотопів НПП «Цуманська пуща»}

\begin{tabular}{|c|c|c|c|}
\hline Біотоп & Згарище & $\begin{array}{c}\text { Сосновий } \\
\text { ліс }\end{array}$ & $\begin{array}{c}\text { Дубовий } \\
\text { ліс }\end{array}$ \\
\hline Згарище & $\mathbf{2 1}$ & 0,28 & 0,48 \\
\hline Сосновий ліс & 4 & $\mathbf{8}$ & 0,44 \\
\hline Дубовий ліс & 12 & 6 & $\mathbf{2 9}$ \\
\hline
\end{tabular}

Примітка. У верхньому правому куті, курсивом подано значення індексу Чекановського-Серенсена; в центрі, жирним шрифтом - кількість видів у кожному біотопі; у нижньому лівому куті - кількість спільних видів.

Для встановлення спільності карабідофауни у різних біотопах парку підраховували індекс подібності фаун (Чекановського-Соренсена). Як видно 3 таблиці 1 , найбільшу спільність мають біотопи дубового лісу і згарища $(0,48)$, середній показник спільності властивий для лісових біотопів (0.44), найменша подібність видового складу турунів властива біотопам соснового лісу та згарища $(0,28)$. Загалом індекси спільності видового складу трьох досліджених ділянок невисокі, оскільки число спільних видів низьке. Таку особливість можна пояснити значними відмінностями умов існування турунів, які створюються у різних біотопах парку.

\section{ВИСНОВКИ}

На території Ківерцівського НПП «Цуманська пуща» зареєстровано 42 види турунів, що належать до 19 родів. Найбільше видове різноманіття має рід Pterostichus, до якого належить 8 видів. Тільки на згарищі зареєстровані 8 видів: Agonum sexpunctatum, Amara communis, Amara curta, Amara tibialis, Bembidion lampros, Dyschirius globosus, Poecilus versicolor, Pterostichus minor, лише в сосновому лісі виявлено Amara familiaris, лише в дубовому лісі трапляються 15 видів: Agonum gracilipes, Amara aenea, Calosoma inquisitor, Carabus coriaceus, Carabus hortensis, Harpalus latus, Leistus rufomarginatus, Leistus terminates, Limodromus assimilis, Nebria brevicollis, Notiophilus biguttatus, Pterostichus melanarius, Pterostichus strenuous, Stomis pumicatus, Synuchus vivalis.

Видове багатство зростає за градієнтом: сосновий ліс - дубовий ліс - згарище. У сосновому лісі індекс Маргалефа становить 1,93 , у дубовому $-3,55$, на колишньому згарищі $-4,42$.

Найбільшу спільність видів турунів мають біотопи дубового лісу і згарища $(0,48)$, середній показник спільності властивий для лісових біотопів $(0,44)$, найменша подібність видового складу турунів властива біотопам соснового лісу та згарища $(0,28)$.

Отримані результати $\epsilon$ попередніми й неповними, тому карабідофауна парку потребує спеціальних досліджень.

\section{Подяки}

Автори щиро вдячні: старшому науковому співробітнику, завідувачу відділу музейного обліку біоресурсів Державного природознавчого музею НАН України Володимиру Різуну за надані консультації 3 визначення видів, к.б.н., вченому секретареві Державного природознавчого музею НАН України Г. В. Середюк, директорові КНПП «Цуманська пуща» I. С Квачу, колишньому начальнику 
відділу науково-дослідної роботи С. С. Штокалу, виконуючому обов'язки начальника 3 охорони природи Лопатенського ПОНДВ Р. В. Бутейцю за допомогу в організації та проведенні досліджень.

\section{ЛІТЕРАТУРА}

1. Берест, 3. Л.; Плющ, І. Г.; Шешурак, П. М.; Титар, В. М.; Зінченко, О. П.; Сухомлін, К. Б.; Васильєва, Ю.С. Уточнення і доповнення до списків комах, які охороняються у Волинській області України. Заповідна справа в Украӥні. 2006, 12 (1), с 66-73.

2. Літопис природи Ківериівського національного природного парку «Цуманська пущза». T. 32018 р.; КНПП «Цуманська пуща»: Ківерці, 2019.

3. Кравченко, О.М. Поширення жуківтурунів (Coleoptera, Carabidae) на території Шацького національного природного парку. Науковий вісник Волинського національного університету імені Лесі Украӥнки. Серія Біологічні науки. 2009, 2, с 144-148.

4. Різун, В. Б., Чумак, В. О. До вивчення жуків-турунів (Coleoptera, Carabidae) Волинського Полісся. Природа Західного Полісся та прилеглих територій: зб. наук. пр. / Волин. нац. ун-т імені Лесі Українки; відп. ред. Ф. В. Зузук та ін. Луцьк, 2010. №7. c 149-153.

5. Фасулати, К. К. Полевое изучение наземных беспозвоночных. Высш. шк.: Москва, $1971.424 \mathrm{c}$.

6. Schmalhausen Institute of Zoology NAS, Ukrainian Biodiversity Information Network. URL: http://ukrbin.com (accessed Des. 23, 2020).

7. Горностаев, Г.Н. Насекомые СССР; Мысль: Москва, 1970.

8. Мамаев, Б. М.; Медведев, Л. Н.; Правдин, Ф. Н. Определитель насекомых европейской части СССР; Просвещение: Москва, 1976.

9. Жесткокрылые и веерокрылые; Гурьева, Е. Л.; Крыжановский, О. Л. Ред.; В Определитель насекомых европейской части СССР в пяти томах; Бей-Биенко, Г.Я. Ред.; Определители по фауне СССР, изд. Зоол. ин-том АН СССР; Наука: МоскваЛенинград, 1965; Т. 2, Вып. 89.

10. Зоологический институт Российской академии наук. Жуки (Coleoptera) и колеоптерологи. URL: https://www.zin.ru/Animalia/Coleoptera/rus/ (дата звернення: жов. 10, 2019). 